\title{
Students' Perception On The Implementation Of Intensive English Course For Freshmen At Universitas Indonesia Timur: A Program Evaluation
}

\section{(Persepsi Mahasiswa Terhadap Penerapan Pengajaran Bahasa Inggris Intensif Untuk Mahasiswa Baru Di Universitas Indonesia Timur: Evaluasi Program)}

\author{
Ridwan Nur \\ Dosen STKIP Hermon Timika, Papua \\ Email: ridwannurrappokaleleng@ gmail.com
}

\begin{abstract}
This research was aimed at identifying students' perception on the implementation of IEC at UIT, to evaluate the program based on the students' perception and to find out the virtues and weaknesses found during the implementation of the program from the five aspects namely materials, teaching techniques, time allocation, language use, and the importance of the program.This research employed a descriptive survey method. The population of this research was the first semester students of Health Analyst Department, Midwifery Department, and Nursing Department. One class was chosen from each department. There were sixty students as the sample of the research. They were given questionnaire at the end of the semester. They were also interviewed in relation to the implementation of intensive English course. The researcher also took some documentations to gain the supporting data. Based on the findings and discussion, all the students perceived that the intensive English course is a very good and important program to develop their communication ability especially their English language skill. From the aspect of materials, the students stated that the materials were good and appropriate to their English needs as health department students but some stated that the materials were difficult to understand and memorized. From the aspect of teaching technique, the students stated that they liked to be taught by different instructors because they provided different ways of teaching and they were nice and funny so it makes the class more enjoyable and comfortable. Some students stated that not all the instructors were good in delivering the materials. Also there was an instructor who always uses the same technique in every meeting and there was no variation, so they feel boring to study. From the aspect of time allocation, the students thought that five meetings in a week are enough and effective for them but many of them thought that an hour in a meeting is not enough to study moreover if the instructors came late. From the aspect of language use, the students stated that they always tried to use English when they wanted to speak to their friends and foreigners and they always active in every activity in the classroom like in discussion and ask a question. The others said that they could not speak English well because they did not have sufficient vocabularies and they did not understand how to translate English sentences into Indonesian. From the aspect of the importance of the program, all students concluded that the program was very important to develop their communication ability for their future with various reasons.
\end{abstract}

Key words: Students’ Perception, Intensive English Course, and Program Evaluation.

\section{INTRODUCTION}

Basically, education is a process to help the learners improve themselves to face every changes and problems in their life. There are some problems in education to solve till nowadays, one of the problems is the quality of education itself. The problem of the quality of education in Indonesia is a great scale problem that has happens in a very long time in Indonesia. One aspect that should be improved from the quality of education is the learners' communication ability. Furthermore, the way to improve the learners' communication ability is by improving their foreign language skills. 
Learning English is considered as an important thing to improve the foreign language skill of the learners in Indonesia. Many schools, colleges, and universities include English as one of the important subjects in their curriculum. Also, English is considered as the most important foreign language to learn in Indonesia. Mostly university students have high motivation in learning English but they still cannot achieve good English proficiency and inability to use the target language as a means of communication because of some factors such as supportive environment, motivation, and the intensity of learning English.

To facilitate this process, the authorities of language centers ought to organize optimal schedules based on the learners' needs and talents. One important, though not the most important, skill they need in this path, is a good knowledge of English as a means of communication which would assist them not only during the academic years, but also in their job hunting, career performance, international conference participations, etc. (Nasiri \& Shokrpour, 2012). Here it is the responsibility for each institution especially for the university to set an English language program to improve the students' foreign language skill and to prepare their students to get the good career after finishing their study. It can also be a great value for the students to learn English although they are not from English Major because many companies nowadays require English as one of the employment requirements. Tunc (2010) states that a language teaching program is a series of foreign language courses teaching the language through some kind of methodology so as to fulfill aim/aims such as communication or passing a proficiency exam. That is why most students in university are paying high attention on English learning program. Besides that intensive English program could have a significant positive effect on language knowledge development of the learners. Intensive program can also lead to learners' better attendance and concentration.
This study will investigate the students' perception on the implementation of intensive English Course at UIT (Universitas Indonesia Timur) in Makassar city because the university has designed a new Intensive English Language Program in which all new students in three study programs namely Midwifery Program, Health Analyst Program, and Nursery Program were required to attend five English classes in a week. This is a new English language program and had been applied for one semester

The students are obligated in the three study programs to attend intensive English classes in a week which are divided into five English classes namely speaking class, writing class, vocabulary class, pronunciation class, and grammar class. The total of the meeting for each class are sixteen meetings, so the students will have sixty meetings till the end of the semester. It is also expected that the learners will show high attention toward the English learning program and to show high English proficiency as the result of the intensive program. The materials provided in the course are integrated so the students can apply continuously what they have gotten in one class to another class as the aims to familiarize them with English. As stated above that the main goal of the program is to improve the students' communication ability especially English language skill in order to make them success in their carrier.

Later, the researcher will evaluate the intensive English program based on the students' perception because in this case the students are the direct objects who directly get and feel the intensive program as they are required to attend it. The purpose of this research is to see whether there is an advantage or virtues and weaknesses or disadvantages during attending the program. Also, for the other things which may occur during the program that can become an important source for the educational institution to be reorganized in the future as Murphy (2000) defines that evaluation as a way to determine the degree in which a program is effective in terms of its 
objectives. At the same time, it supports the stakeholders in decision making for program improvement through careful analysis of information gathered.

According to Rea-Dickins and Germaine (1993), evaluation is an intrinsic part of teaching and learning. It is important for the teacher because it can provide a wealth of information to use for the future direction of classroom practice, for the planning of courses, and for the management of learning tasks and students. Evaluation has a different overall focus and several different purposes from student assessment. It may evaluate our language teaching methods, our materials, and our effectiveness as teachers and so on, that we actually know what it is we are evaluating. They are all part of the curriculum, of the full range of activities which take place both prior to and during the implementation of a learning program.

According to Murphy (2000) defines evaluation as a way to determine the degree in which a program is effective in terms of its objectives. At the same time, it gives support to stakeholders in decision making for program improvement through careful analysis of information gathered. In this case, it is believed that evaluation has evolved from focused studies of teaching methods inspired by language learning theories to a curriculum management enterprise with a focus on quality assurance and enhancement. It is hoped that through this research, the virtues that the students get can be maintained and on the contrary the weaknesses or the problems can be fixed in order to create a good English language program as the answer to improve the students' foreign language skill.

Evaluation is the systematic assessment of the worth or merit of some object. This definition is hardly perfect. There are many types of evaluations that do not necessarily result in an assessment of worth or merit such as descriptive studies, implementation analyses, and formative evaluations, to name a few. Better perhaps is a definition that emphasizes the information-processing and feedback functions of evaluation. For instance, one might say: Evaluation is the systematic acquisition and assessment of information to provide useful feedback about some object. Both definitions agree that evaluation is a systematic endeavor and both use the deliberately ambiguous term 'object' which could refer to a program, policy, technology, person, need, activity, and so on. The latter definition emphasizes acquiring and assessing information rather than assessing worth or merit because all evaluation work involves collecting and sifting through data, making judgments about the validity of the information and of inferences we derive from it, whether or not an assessment of worth or merit results.

The statement above becomes an important source for the researcher to conduct evaluation of the intensive English course because it provides explanation on why we need to evaluate program and what aspects that we need to focus on evaluate something.

In this case, the researcher will conduct an evaluation on the advantages and disadvantageous of the implementation of intensive English course for freshmen to see whether there is virtues of the program that the students feel need to be changed. More specifically, from a course evaluation we would expect not only to understand better what is good and bad about the program, but also to gain feedback in terms of an explanation as to which factors contribute to the 'good' and to the 'bad' aspects of the program.

It is also important to know why we need to do an evaluation. Evaluation may be undertaken for three principal reasons:

- Accountability

Accountability means transparency and responsibility deals with the management of the program by the educational institution in order to create a better model of service to the students so any complains or problems occurred can be accommodated for a better program in the future. 
- Curriculum development and betterment Evaluation is important to do or curriculum development and betterment in order to revise and reorganize the curriculum is the purpose why evaluation is needed to do because curriculum involves the entire learning program and its features and the students' perception as the most valuable source because they are the subjects that directly feel the achievement after joining the program.

- Self-development: teachers and other language teaching professionals

Evaluation is important to do in order to improve the teaching skills and to be more creative is the other purpose why we need to do evaluation. As time expanding, so as the teaching methods from the reflection of the continual learning process also change. The teachers need to use various ways of teaching in order to attract the students in learning so through evaluation it can be identify what aspects that the teachers should change, modify, or even maintained.

In this case, the researcher has decided the purpose of conducting this evaluation for the development and betterment of the curriculum and the program in the institution to make the students meet their needs in learning English. The other purposes of conducting evaluation are recommended for other future research in making the quality of English learning more various.

According to Wodkowsky (2003), Intensive English programs, also called accelerated or compressed courses, are the programs in which the students go through a relatively higher number of sessions in a shorter period than normal. The effectiveness of intensive courses has been a matter of controversy in recent years. This statement shows that there is highly intensity of meeting in intensive program that the students should attend.

Intensive courses also known as accelerated, time-shortened, block format, compressed course, flexible, as well as alternative are the courses in which the number of sessions or the length of course or class time is shorter than the usual format of the schedule (Scott \& Conrad, 1992). Elsewhere, also, Intensive English Program has been mentioned as an important step in developing not only the students' basic interpersonal communication skill but more importantly their cognitive academic language proficiency. So, there are two advantageous that the learners get through the intensive English program.

From the statements above, it can be concluded that intensive English program is truly organized in certain periods shorter than the regular one to make the students learn English more and to develop their communication skills. On the positive side, the rationale for introducing intensive courses in schools is embedded in the area that teachers do not have enough time to teach using more effective, active learning methods in the usual traditional schedules. It is hoped that the students can increase their motivation, commitment and engagement during the program conducted in intensive formats and the students can perceive intensive programs as much more intense, more stimulating, more exciting, and more enjoyable.

\section{RESEARCH METHODOLOGY}

This research applied descriptive survey method to describe the students' perception on the implementation of intensive English course. This research will evaluate the program by surveying from the students' perception without connecting it with other variables in order to get more accurate and more specific description of the program. In evaluating the program, the researcher will focus on the process during the implementation of the intensive course and not discussed any other aspect that can be evaluated such as the context, input, or the product. This research using CIPP Models Evaluation by Stufflebeam (1983) that evaluate a program by using four aspects above but a researcher can only focus on one aspect in order to make it more specific and obvious. This research used 
questionnaire as a survey and an open-ended question as interview to see the students' perception on the implementation of intensive English course and to confirm it with the students' perceptions in questionnaire.

The questionnaire used in this research fit the situation felt by students during the process of the implementation of the program, only items about students' perception toward English intensive course and their learning orientations were retained; other items such as classroom anxiety were omitted because the students did not take any English courses when they participated in the study. The questionnaire was designed in 20 questions and it consisted of five main categories which were used as references to evaluate the program namely teaching techniques, time allocation, materials, communication activity, and the importance of the program. At the end of the survey, an openended question as interview was added. The interviews then analyzed based on each items and explained through description method. Both questionnaires and interviews analyzed in the form of descriptive data. So, the researcher provided the description of the implementation of the intensive English course based on the students' perception.

The population of the research was the first semester students from three study programs in Nurse Faculty and Public Health Faculty of Universitas Indoesia Timur namely Midwifery Study Program, Health Analyst Study Program, and Nursery Study Program 2012/2013 academic years. The number of population was 600 students, consisting of 24 classes and each class consists of 25 students.

The sample of this research used purposive sampling because this university had many classes so the researcher only chose three classes as the representatives of the research subject. The researcher took one class from each study program. As Gay (2006) states that purposive sampling is the process of selecting a sample in such a way that all individuals in the defined population have an equal and independent chance of being selected for the sample. So, there were 60 students who participated in this research.

Triangulation method was used in this research to strengthen the information as the result gathered for evaluation and findings. In this case, the researcher used two kinds of instruments namely questionnaire and interview as the result to show the students' perception. As Guion (2002) states that triangulation is a method used by qualitative researchers to check and establish validity in their studies. Triangulation involves using more than one method in qualitative research to avoid bias and to provide more factual result of the program. The researcher used methodological triangulation to analyze the findings based on the data collection level. The researcher integrated and coordinated the result gained both from questionnaire and interviews. So, it is hoped that the result from questionnaire would strengthen and complete the result from interviews.

The questionnaire items were translated into English and administered to students. The questionnaire was first piloted to a small sample and then administered to 60 second semester students in three classes by their content course teachers on the same day in the middle of the second term of the academic year 2012 - 2013. The students were asked to finish the survey within 25 minutes during the normal teaching method. All the questionnaires were collected by the teachers and given to the researcher and the questionnaires would be completed in descriptive analysis.

There were twenty questions in the questionnaire and three questions in interview related to intensive English course. The researcher employed twenty questions to each questionnaire and three questions in interview because those are believe represent the students' perceptions regarding intensive English course being implemented at Universitas Indonesia Timur. The interview and questionnaire distribution were scheduled at university. Before interviewing and distributing questionnaire, the researcher welcomed the 
participants, introduced himself to the participants and provided an overview of the research. After that, the researcher administered the questionnaires to the students and then conducting interview by calling the students one by one.

Both questionnaires and interview were analyzed in the form of descriptive data, as well. Note-taking technique was used. All the answers of the interviewees were analyzed by categorizing the points that came out from the statements for each question. In addition, thematic analysis and grouping of the answers from different interviewees to the same or similar questions were employed for the analysis of interview. The content analysis was carried out. Answers from different interviewees to common questions or perspectives on central issues were categorized under five main categories. These categories were formed with regard to teaching techniques, materials, time allocation, language use, and the importance of the program. First, statements to the interview were grouped under each related categories. The statements which presented a different point were listed one by one. The similar statements were listed below the related categories and also the frequencies for the repeating ideas were obtained. This technique of data analysis was modified from Kabi (2011) and Pana (2009) who describe and elaborate the students' perception into table of percentage and describe the data by using aspects or indicators of students' perception.

\section{FINDINGS AND DISCUSSION}

\section{Virtues and Weaknesses found during the Implementation of the Program by Five Indicators.}

Based on the data collected from questionnaires show that students of the three study programs in Universitas Indonesia Timur tell their perceptions on the process during the implementation of the program by explaining the virtues and weaknesses they perceive from each category in a simple way. The questionnaire consists of twenty items and each item represents the indicators to evaluate the program.

Below are the students' perception on the virtues and weaknesses found during the implementation of the program by five indicators namely materials, teaching technique, time allocation, language use, and the importance of the program that obtained from questionnaire that submitted by the students at the end of the class in order to see the value of the program

\section{A. Materials}

The materials used in the intensive English course divided into five different classes namely speaking class, grammar class, writing class, vocabulary class, and pronunciation class. There are four items in the questionnaire represents the questions about the students' perception on the materials; they are item 3, 6, 15, and 20. All the students learn the materials that related to the skills in each class. The materials are also integrated so the students usually continue learning what they get in one class to another class in order to reinforce their skills and memory and make them to use English as frequently as possible. The materials are not only contains general English but also the specific one related to the students' department. In this case, they are from health department so the materials are about health.

In pronunciation class, the students learn how to produce and pronounce the vowels and consonants sound in appropriate way. They were taught to identify the phonetics and the types of each letters in English. They were given list of words that represent the phonetics symbols of a letter. They also watched the videos that showed the technique to pronounce a sound. Until the end of the meetings, the students always practice pronouncing the phonetic symbols and the words in order to make them fluent. In vocabulary class, the students were provided by the list of daily expressions and conversation related to daily activities and 
their major as health students. So, the students not only learn about general English but also the specific one. This class is very helpful to engage the students to speak because it provides important vocabularies that the students need for their communication. In grammar class, the students learn about how to construct a sentence in the right way. They studied about the rules of English grammar and they have to identify the organization of a sentence. They also studied about part of speech which is very important to analyze the kinds of words in English to support their grammar comprehension. In writing class, the students were taught to improve their writing skill. They were given list of words that they can make it to become a sentence. Although the purpose of the program is to develop the students' communication ability but it can be considered that they need writing skill to support their career performance in the future. The last, in speaking class, the students were trained to build their self confidence to speak. They must be able to share, express, and show their opinions and feelings in appropriate way. They learnt how to build a good communication with other people and how to handle patients because it becomes the goal of the course in order to give language skill to the students after them graduate from the university and ready to compete with the other people.

The materials are compiled from many sources by the team consists of the instructors. The students handle five books contain the materials in each class. The materials in each class are expected to motivate and engage the students to learn English and to show their positive attitude toward the program. The materials are started from the basic level to the upper level to adjust the students' level. Of 60 respondents, most of the students tell their perceptions about the virtues of the materials learnt in the course as follows.
1. The materials are interesting and quite fulfill the learners' language needs. In this case, the students are from health department so the materials in this course are not only about general English but also about health.

2. The materials relate to daily life, conversation, and activities. The materials also attached by dialogues relate to health world. For example how to handle a patient, how to welcome a patient in hospital, or how to accompany a patient to care units or to operation theatre.

3. The materials begin from the basic level to upper level so the students are easy to understand them.

4. The materials train the students how to communicate, socialize, and to develop their self-confidence in speaking.

5. The materials are fun, not boring, easy to understand, usually accompanied by games, various, but depends on the way the lecturers deliver them.

6. The materials also contain assignments that engage the students to study so the students can review what they have learnt at home because if there is no assignment they are lazy to study and review the materials.

The materials also contain some important English terms related to health that the students usually find in other subjects or articles like in anatomy class, psychological of maternity, chemistry, obstetrician, and biology.

B. Teaching Technique

Each of the five English classes in this course was taught by different English instructors. Each instructors applied different methods in teaching the students so there are several of teaching techniques applied in this course. Some of the instructors graduated from graduate programs of some universities and some of them still continuing their study in graduate program. So all the instructors are qualified and have enough experience in teaching 
English because almost all of them are from education department. Those of the teaching techniques delivered by the instructors were expected to build the students' enthusiasm in learning English and to lead them to better concentration. There are two items in the questionnaire represents the questions about the students' perception on the teaching technique; they are item 1 and 19.

The way the lecturers deliver the materials and manage the class will determine and shape the students' perception toward the quality of a learning system. A good teacher should be aware and understand the students' condition and guide them wisely to be a good model for the students. Teachers have to create a good and safe classroom circumstance in order to make the students feel comfortable and desire to study so they can believe on their lecturers' competence. Of 60 respondents, most of the students tell their perceptions about the virtues of the teaching technique applied by the instructors in the course as follows.

1. The instructors in delivering the materials are nice, fun, and humorous.

2. The way the instructors deliver the materials are understandable so the students feel comfortable to study English.

3. The students were taught by different instructors so there were also different methods and that makes the students are not boring because they provide various ways of teaching.

4. The instructors in delivering the materials usually apply learning by doing technique so the students were expected to directly apply while they were learning the materials. For example, in material about 'asking for and giving direction', the students can identify the prepositions and instructions in giving directions to someone while they can simulate with their friends supposed to look for a place.

5. There are some other techniques that the instructors usually apply in the classroom such as Total Physical Response (TPR), classroom discussion, playing games, singing songs, making and practicing conversations, role play, lecturing, and audio lingual method. Those techniques are expected to more engage and motivate the students to learn.

6. The instructors mediate and facilitate the students to learn and they have to attract the students to speak and to build the students' self-confidence.

7. The instructors also usually give assignments and guide the students if they need a help. The students are happy because they can know and meet with different characters from many teachers. They say that to be taught by different teachers, they can get many more knowledge.

C. Time Allocation

The students have the obligation to attend five English classes in a week with different English domains. It took an hour in a meeting. The times are adjusted with the students' other regular schedule so they will feel comfortable to learn English without disturbing the other important subjects. The students need to learn English as frequently as possible in order to make it their habit and that becomes the purpose of this program. To practice producing English sentences, there should be a medium for the students to learn and through this intensive English course, the students are facilitated to build their self confidence, to express their opinions and feelings, and to share or discuss with their friends in English. Those are the considerations of conducting this program in order to improve the students' communication ability especially their foreign language skill. In this path, the skill they need is English because English has 
become international language that can be used by the students to be successful in their career as professional health workers.

There are two items in the questionnaire represents the questions about the students' perception on the time allocation; they are item 2 and 16.

The students were expected to show good English proficiency if they learn English in intensive meetings. The more they practice English, the more confidence and fluent they are. The more often we study, the more knowledge we get, and that is the students' perception toward the time allocation in this program. Time allocation is expected to engage the students' frequency in using English. Because this is an intensive English course means the students were expected as often as possible to use English in order to make it their habit and become the part of their life. This is one of the purposes of the program to accustom the students with English in order they can compete with other people and give them one life skill namely English skill. Of 60 respondents, most of the students tell their perceptions about the time allocation in the course as follows.

1. All the students perceive that learning English five times in a week is enough and effective for them.

2. The students consider that it would be better if they study English every day.

3. The students think that they need more available time to understand the materials but it is quite difficult to do because they also have many regular subjects related to their department.

4. Some of the students consider that an hour for each meeting is not enough to study moreover if the instructors come late.

D. Language Use

From this category, we can identify the intensity of using English when the students studying in the classroom. How active they use English when they are studying and communicating with their friends or lecturers. Also, the students' perception would be identified on the result of their English achievement to know whether their English skills have been improved after joining the program. The activities that the students join will show how intensively they practice their English. The way they use English as the target language as a means of communication will show their seriousness in studying and that would become indicator of the successful of teaching and learning in the classroom.

The students should be more active and more participate in every class activity in order to improve their self confidence and their communication ability. In this case, the instructors were the facilitators and mediators among the students to improve themselves. The students should optimally engage to speak up and tell their opinions and express their feeling in front of their friends in the right way. They will master English if they use English in their daily conversations. Not only at university but also outside of it, for instance they want to communicate with their friends at home or have a little chit chat on internet with new friends from abroad. The students should practice their English in maximum way because it will be good for them and for their future if they want to become successful as professional health workers.

There are five items in the questionnaire represents the questions about the language use by the students; they are item 4, 5, 11, 14 , and 17 . Of 60 respondents, most of the students tell their perceptions language use in the course as follows.

1. The students think that now they have been able to communicate with their friends and other people in English and they also know many new vocabularies. They also can make English sentences by themselves.

2. Although what they know are still little but they think that the knowledge they 
receive in the program is more than enough.

3. The students also always try to practice using English at home. They said that previously they really don't understand English but now they have started to understand because they always active in the classroom discussion and pay attention in the lesson well.

4. Some of them said that in the past they were lazy to study English but now they have started to love English.

5. The students usually train themselves to speak English when they are doing exercises, answering questions, translating sentences, and reading texts because they think that the materials are interesting, motivate them to study, and require them to speak and give arguments in English so as the lecturers who usually invite them to be active and participate in the classroom, ask the students with a question, ask for clarification, and give opportunity to tell their opinions. Those are the reasons why the students want to learn and improve their English skills by participating and to be active in the classroom.

6. The students also get good score in English and that makes them proud.

7. They can speak with native speakers because they can read English books and can chat on the internet with foreigners.

8. The other say that they cannot speak English well because they lack of vocabularies so they don't know how to say that in English and they don't understand how to translate English sentences into Indonesian.

E. The Importance of the Program

In this part of the questionnaire, it was aimed to find out the real students' perception toward the importance of the program for their carrier in the future. The students must be able to explain why they think that this program is important or not. The students' perception toward the importance of the program is the most valuable source to evaluate the program because they are the subjects that directly feel and get the whole experiences during the process of the implementation of the entire program. As explained previously that this intensive English course is very important to develop the students' communication ability especially their foreign language skill. Through this program, the students are trained to improve their English language related to their own reasons.

There are seven items in the questionnaire represents the questions about the importance of the program based on the students' perception; they are item 7, 8, 9, $10,12,13$, and 18 . Of 60 respondents, most of the students tell their perceptions on the importance of the program as follows.

1. All the students think that this program is very good and very important to improve their communication ability because they think that English is an international language so they have to master it for some reasons such as to fulfill their language needs as students of health department.

2. Besides that they also have the other reasons such as to be advance in their carrier, to be a good and smart person, to get good achievement of English and be able to speak English, to face the globalization era, to improve the quality of human resources, to face the final exams, to compete in ASEAN Free Trade Area (AFTA), to seek for a job in abroad like working in international hospitals, to travel around the world, and to become professional workers.

3. The students learn English intensively through this program so they think that the more they learn 
English the further their ability to speak English and they think that English should be frequently practiced every day.

4. In this program, the students learn many things and gain knowledge such as pronunciation, grammar, vocabulary, writing, and speaking and many more English terms so the students not only learn general English but also the specific one. The materials are also about health related to their department so they consider that it is important to learn English through this program.

From the students' reasons above, we can say that intensive English course is a very important program for all people who want to be professional workers in any field of job because English is considered as international language. Moreover, nowadays we are coming to globalization era that demands us to be able to communicate with many people from other countries.

\section{CONCLUSION}

There are some conclusions related to the findings and discussion in the previous chapter. The intensive English course is a very good and important program to develop the students' communication ability especially foreign language skill. All the students tell their perception toward the implementation of the intensive English course in positive views and they think that their English skill improves by the evidence they have been able to communicate with their friends and foreigners in English, can read English texts and interpret the message in English, can construct sentences and translate Indonesian to English and vice versa.

The students give their perceptions by looking at the aspect of materials, teaching techniques, time allocation, language use, and the importance of the program in good impression. They tell that the materials are interesting for them so they are motivated and enjoy to study by using the materials. From the aspect of teaching technique, students like to be taught by different instructors because they provide various way of teaching. The instructors also kind, clear, funny, and motivate the students to be active in the classroom. From the aspect of time allocation, the students consider five meetings in a week are enough because they also have other regular subjects. But some of them consider that an hour in a meeting is not enough. From the aspect of language use, the students realize English is important when they want to communicate with their friends so they always try to be active in every activity. The last, from the aspect of the importance of the program, all the students think that this program is very important to develop their communication ability.

\section{BIBLIOGRAPHY}

AL-Wreikat, Y. A. A. S. \& Kabilan, M. K. 2010. An evaluation of Jordanian EFL Teachers' In-service Training Courses Teaching Techniques Effectiveness. (Online) Vol. 3, No. 4. (http://www.ccsenet.org/elt, Accessed on March $\left.17^{\text {th }}, 2014\right)$.

Gage, N. L \& Berliner, D. C. 1984. Educational Psychology. Third Edition. Houghton Mifflin Company.

Gay, L. R. 2006. Educational Research: Competencies for Analysis and Applications. Pearson Merrill Prentice Hall.

Gonzales, R. DLC. 2010. Motivational Orientation in Foreign Language Learning: The Case of Filipino Foreign Language Learners. TESOL Journal, 3 (2), 15-17. http://www.tesoljournal.com

Guion, L. A. 2002. Triangulation: Establishing the Validity of Qualitative Studies. Institute of Food and Agricultural Sciences. University of Florida. Online Publication. Accessed on May $10^{\text {th }}$, 2014. 
Hutchinson, T. \& Waters, A. 1991. English for Spesific Purposes. A learning-centered approach. Cambridge University Press.

Intensive English Language Program Guide. 2010. International Student Program in Victorian Government Schools. Department of Education and Early Childhood Development, Melbourne, Victoria.

Kabi, Aritje. 2011. The Implementation of Bilingual Program at Rintisan Sekolah Bertaraf Internasional (RSBI) SMP Negeri 12 Makassar. Thesis. Makassar: Program Pascasarjana UNM Makassar.

Kelly, Mary. 2012. Student Evaluations of Teaching Effectiveness: Considerations for Ontario Universities. Online Journal. Accessed on August 18 ${ }^{\text {th }}, 2014$.

Kvale, S. 1996. Interviews: An Introduction to Qualitative Research Interviewing. Thousands Oaks, CA: Sage.

Liu, Meihua. 2007. Chinese Students' Motivation to Learn English at the Tertiary Level. Asian EFL Journal, 9 (1). http://www.asian-efl-journal.com

Moleong, L. J. 2007. Methodology Penelitian Kualitatif. Makassar: Program Pascasarjana UNM Makassar.

Mukundan, J. 2012. The Effect of an Intensive English Program on Malaysian Secondary School Students' Language Proficiency. Journal on Canadian Center of Science and Education, 11. 5. http://dx.doi.org/10.5539/elt.v5n11p1

Murphy, D. F. 2000. Key Concepts in ELT, Evaluation. ELT Journal, 54(2), 210211. http://dx.doi.org/10.1093/elt/54.2.210

Nasiri, E. \& Shokrpour, N. 2012. Comparison of Intensive and Non-intensive English Courses and Their Effects on the Students' Performance in an EFL University Context. European scientific journal, April Vol. 8, No. 8.

Notebaert, A. J. 2009. Students' perceptions about learning anatomy. Published Dissertation. Iowa: University of Iowa.
Nunan, D. 1992. Research Methods in Language Learning. Cambridge: Cambridge University Press.

Pana, Kaimuddin. 2009. English Syllabus Design for College Students of Avionic Technology Makassar. A Dissertation. University of Hasanuddin.

Rea-Dickins, P. \& Germaine, K. 1993. Language Teaching: A Scheme for Teacher Education. Oxford University Press.

Schunk, D. H. \& Meece, J. L. 2009. Students' Perceptions in the classroom. Lawrence Erlbaum Associates, Inc.

Scott, P. A. \& Conrad, C. F. 1991. "A Critique of Intensive Courses and Agenda for Reseach." Madrison WI: Division of Summer Sessions and Inter-college programs, university of Wisconsin. ERIC ND. ED 337097

Smith, K. Q. N. 2008. Learning styles and students' perception of teachers' attitudes and its relation to truancy among African American students in Secondary education. Published dissertation. Lousiana: Lousiana State University.

Stufflebeam, D. L. 1983. The CIPP Model for Program Evaluation. Boston: KluwerNijhoff.

Ting, K. F. 1998. Measuring Teaching Quality in Hong Kong's Higher Education: Reliability and Validity of Student ratings. Hong Kong polytechnic University, Educational Development Centre.

Tunc, Ferda. 2010. Evaluation of an English Langauge Teaching Program at a Public University Using CIPP Model. (Master Thesis). Middle East Technical University, Turkey.

Wode J. \& Keiser J. 2011. Online Course Evaluation Literature Review and Findings. Academic Affairs Columbia College Chicago.

Wodkowsky, R. J. 2003. Accelerated learning in colleges and universities. New 
Jurnal Ilmu Sosial dan Pendidikan

Vol. 4. No. 3 Juli 2020

http://ejournal.mandalanursa.org/index.php/JISIP/index

Terakreditasi Peringkat 5 (No. SK: 85/M/KPT/2020)

Directions for Adult and Continuing Education, $\quad 97, \quad 5-15$.

http://dx.doi.org/10.1002/ace.84 